Research Article, Issue 1
Analytical Methods in Environmental Chemistry Journal
AMECJ

\title{
Analytical Methods: Electrochemical azido-selenenylation of some olefins by cyclic voltammetry and controlled-potential coulometry
}

\author{
Ahmad Rouhollahi ${ }^{\text {a,* }}$, Zeenat Asgharia ${ }^{\mathrm{a}}$, and Barahman Movassagh ${ }^{\mathrm{a}}$ \\ ${ }^{a}$ Chemistry Department, Faculty of Science, K.N. Toosi University of Technology, Tehran 15418, Iran.
}

A R T I C L E I N F O:

Received 7 Aug 2018

Revised form 5 Oct 2018

Accepted 15 Nov 2018

Available online 17 Dec 2018

Keywords:

Electrosynthesis

Diphenyl diselenide

Markovnikov

Cyclic voltammetry

Controlled-potential coulometry

\begin{abstract}
A B S T RA C T
Electrochemical azido-phenylselenenylation of some olefins was studied with the oxidation of diphenyl diselenide in the presence of some olefins and sodium azide in dimethyl formamide containing tetra butyl ammonium perchlorate as supporting electrolyte in an H-type cell. The electrochemical oxidation of the mixture of $(\mathrm{PhSe})_{2}$, olefins, and $\mathrm{NaN}_{3}$ was studied by cyclic voltammetry and controlled-potential coulometry. Anti product can be obtained with Markovnikov orientation. This product was characterized .by ${ }^{1} \mathrm{H},{ }^{13} \mathrm{C}$ NMR, and IR spectroscopy
\end{abstract}

\section{Introduction}

Selenium is a biologically essential element for all vertebrates.Anumberoforganoseleniumcompounds have been found in living tissue: Selenocoenzyme A, Selenobiotine, Se-methyl Selenomethionine, Selenosystathione, Selenohomocystine, Selenocystine, Selenomethionine, etc. Moreover, Selenium is also known to help prevent cancer and cardiovascular diseases [1-7]. Despite the similarities between sulfur containing molecules and their selenium congeners, there are several unique

* E-mail: rouhollahi@kntu.ac.ir https://doi.org/10.24200/amecj.v1.i01.38 features of organoselenium compounds. They can be used in nucleophilic, in electrophilic, as well as in radical reactions [8]. Organoselenium compounds have found applications as oxygen transfer reagents in organic and organometallic synthesis and as oxygendonor ligands in main and transition metal complexes [9]. Also, diselenides are known as mediators, redox catalyst and important precursors in organic electrosynthesis. It is evident that investigations of reactivity and redox mechanisms of organic Selenium compounds are of great importance today. Diaryl diselenide themselves can serve in electrosynthesis 
as mediators in indirect electrolyses of organic compounds, as redox catalysts for reduction of protons, oxidation of water or derivatization of olefins, as a trap for new complexes [1]. The chemistry of organoselenium compounds has been extensively investigated because of their utility in organic synthesis [2, 10-12]. The reaction of carboncarbon double bonds with selenium electrophiles is performed under mild reaction conditions and the reaction products can be used in a variety of subsequent functionalizations [12]. It is well established that addition to unsymmetrical olefins initiated by electrophilic phenylselenium species proceeds through the formation of seleniranium intermediates which, in the presence of external or internal nucleophiles, usually affords anti adducts with prevalent Markovnikov orientation [13]. In addition, the phenylseleno group is an important functionality in organic synthesis because it can be easily introduced into and removed from unsaturated compounds [2, 14]. The products obtained from the azido-selenenylation of alkenes contain the phenylseleno and azido groups which can be used for several conversions [15]. Electrosynthesis is the optimal method for carrying out redox reactions, because it works at normal temperature and has the following advantages [16, 17]. Also, organic electrosynthesis is not a new technique, and there is considerable knowledge of the types of reactions which take place at cathodes and anodes. One view of organic electrochemistry is that it is a unique non-thermal method for activating molecules .Since the rate of reaction can normally be increased by raising the electrode potential, it is possible to carry out reactions with high activation energy at low temperature. Another view is that electrochemistry is an alternative to chemical redox methods [18]. There are several works of phenylseleno group's versatility, including the alkoxylation of alkenes [19], carbonyl compounds [20], and fluoriation of alkenes [21]. Electrochemical cyclization of unsaturated hydroxyl compounds containing phenylselenoetherification and phenylselenolactonization have been reported [22]. In several papers, diphenyl diselenide is used as a catalyst for electrosynthesis of many organic compounds $[12,14]$.

In the present work, the electrochemical oxidation of diphenyl diselenide in the presence of some olefins and $\mathrm{NaN}_{3}$ was examined by cyclic voltammetry and controlled-potential coulometry. The electrochemical generation of phenylselenenyl cation followed the formation of anti adduct by a Markovnikov reaction. The final product was purified by preparative thin layer chromatography and characterized by ${ }^{1} \mathrm{H}$ NMR, ${ }^{13} \mathrm{C}$ NMR, and IR spectroscopy.

\section{Experimental Procedure}

\subsection{Instruments}

Cyclic voltammetry and controlled-potential coulometry was performed with an Autolab potentiostat/galvanostat, PGSTAT 30 (Eco Chemie, Utrecht, The Netherlands).

The set-up was used a three-electrode cell with a platinum disc (2 $\mathrm{mm}$ diameter) as the working electrode, a saturated $\mathrm{Ag} / \mathrm{AgCl}$ double junction reference electrode, and a platinum wire as the auxiliary electrode. A platinum rod with a diameter $(\mathrm{mm})$ and length $(\mathrm{cm})$ as working electrode was used in controlled-potential coulometry. The working electrode potential was followed vs. $\mathrm{Ag} /$ $\mathrm{AgCl}$ double junction reference electrode (from Azar electrode, Iran). Electrosyntheses have been carried out both undivided and divided cells. NMR spectra were recorded on a Bruker AQS-300 Avance Instruments. Thin layer chromatography (TLC) was performed on plastic sheets pre-coated with silica-gel (Merck), and spots were visualized with UV light and iodine tank.

\subsection{Chemicals and reagents}

Diphenyl diselenide, cyclohexene, 1-octene, 1-heptene, styrene, and sodium azide were obtained 
from Merck. Tetra butyl ammonium per chlorate (TBAP) and cyclooctene were purchased from Fluka. Dimethyl formamide was prepared from Aldrich.

\subsection{Experimental procedure}

The $(\mathrm{PhSe})_{2}(0.3 \mathrm{mmol})$ and excess of olefins and $\mathrm{NaN}_{3}$ are dissolved in $20 \mathrm{ml}$ dimethyl formamide. Organic solution is contained $1.5 \mathrm{mmol}$ of TBAP as supporting electrolyte. Constant potential electrolysis of the solution was performed in an $\mathrm{H}$-type divided cell under an air atmosphere at room temperature. Constant potential was chosen $1.96 \mathrm{mV}$ (Vs. $\mathrm{Ag} / \mathrm{AgCl})$. The electrolysis was terminated when the current decayed to $90 \%$ of initiated current. The progress was monitored by cyclic voltammograms and TLC in different times of reaction. At the end of electrolysis, extraction of the cell solution, afforded an organic phase which its solvent is evaporated. Then, the residue purified by preparative thin layer chromatography over silica gel (eluent was a mixture of n-hexane/ ethyl acetate). The product was characterized by ${ }^{1} \mathrm{H}$ NMR, ${ }^{13} \mathrm{C}$ NMR, and IR spectroscopy.

\subsection{Characteristics of products}

2.4.1. 1-phenylseleno -2-(azido)cyclohexane IR (neat) $\left(v_{\text {max }}, \mathrm{cm}^{-1}\right): 2095(\mathrm{~N}=\mathrm{N}-\mathrm{N}-), 1576,1468$, 1263 (=C-H aromatic), 982, 860, 835 and $754 \mathrm{~cm}^{-1}$. ${ }^{1} \mathrm{H}$ NMR, $\delta\left(300 \mathrm{MHz}, \mathrm{CDCl}_{3}\right)$ : 7.63-7.5 (m,2H), $7.33-7.25(\mathrm{~m}, 3 \mathrm{H}), 3.3(\mathrm{dd}, 1 \mathrm{H}, \mathrm{J}=7.9$ and $12.6 \mathrm{~Hz})$, $3.08(\mathrm{dd}, 1 \mathrm{H}, \mathrm{J}=6.5$ and $12.6 \mathrm{~Hz}), 2.15-1.26(\mathrm{~m}$, $8 \mathrm{H}) .{ }^{13} \mathrm{C}-\mathrm{NMR}, \delta\left(75 \mathrm{MHz}, \mathrm{CDCl}_{3}\right): 135.8,134.7$, $129.1,128.0,127.7,127.5,64.5,33.0,31.8,29.7$, 25.8, 21.6.

\subsubsection{1-azido-1-phenyl-2-(phenylseleno)ethane}

IR (neat) $\left(v_{\max }, \mathrm{cm}^{-1}\right): 2103(\mathrm{~N}=\mathrm{N}-\mathrm{N}-), 1660(\mathrm{C}=\mathrm{C})$, 1585, 1476, 1268 (=C-H aromatic), 985, 872, 841 and $764 \mathrm{~cm}^{-1} .{ }^{1} \mathrm{H} \mathrm{NMR}, \delta\left(300 \mathrm{MHz}, \mathrm{CDCl}_{3}\right): 7.60-$ $7.40(\mathrm{~m}, 2 \mathrm{H}), 7.40-7.15(\mathrm{~m}, 8 \mathrm{H}), 4.26(\mathrm{dd}, 1 \mathrm{H}, \mathrm{J}=6.5$ and $7.9 \mathrm{~Hz}), 3.23(\mathrm{dd}, 1 \mathrm{H}, \mathrm{J}=7.9$ and $12.6 \mathrm{~Hz}$ ), 3.18(dd, $1 \mathrm{H}, \mathrm{J}=6.5$ and $12.6 \mathrm{~Hz}) .{ }^{13} \mathrm{C}$ NMR, $\delta(75$ $\left.\mathrm{MHz}, \mathrm{CDCl}_{3}\right): 138.7,133.3,129.2,128.8,126.8$, 127.4, 126.8, 66.0, 33.9.

\subsubsection{1-phenylseleno-2-(azido)octane}

IR (neat) $\left(v_{\max }, \mathrm{cm}^{-1}\right): 2094(\mathrm{~N}=\mathrm{N}-\mathrm{N}-), 1570,1465$, 1259 (=C-H aromatic), 979, 858, 833 and $752 \mathrm{~cm}^{-1}$. ${ }^{1} \mathrm{HNMR}, \delta\left(300 \mathrm{MHz}, \mathrm{CDCl}_{3}\right): 7.61-7.55(\mathrm{~m}, 2 \mathrm{H})$, $7.38-7.32(\mathrm{~m}, 3 \mathrm{H}), 3.41(\mathrm{dd}, 1 \mathrm{H}, \mathrm{J}=4.0$ and $16.0 \mathrm{~Hz})$, $3.37(\mathrm{dd}, 1 \mathrm{H}, \mathrm{J}=8.0$ and $16.0 \mathrm{~Hz}), 3.04-2.94(\mathrm{~m}, 1 \mathrm{H})$, $1.68-0.83(\mathrm{~m}, 13 \mathrm{H}) .{ }^{13} \mathrm{C} \mathrm{NMR}, \delta\left(75 \mathrm{MHz}, \mathrm{CDCl}_{3}\right)$ : 135.2, 133.0, 129.0, 127.9, 55.9, 44.6, 32.4, 31.5, 28.9, 27.4, 22.5, 13.9 .

\subsubsection{1-phenylseleno-2-(azido)cyclooctane} IR (neat) $\left(v_{\max }, \mathrm{cm}^{-1}\right): 2094(\mathrm{~N}=\mathrm{N}-\mathrm{N}-), 1572,1468$, 1261 (=C-H aromatic), 984, 863, 835 and $753 \mathrm{~cm}^{-1}$. ${ }^{1} \mathrm{H}$ NMR, $\delta\left(300 \mathrm{MHz}, \mathrm{CDCl}_{3}\right)$ : 7.8-7.77(m, 2H), $7.3-7.25(\mathrm{~m}, 3 \mathrm{H}), 3.70(\mathrm{dd}, 1 \mathrm{H}, \mathrm{J}=4.0$ and $16.0 \mathrm{~Hz})$, $3.15(\mathrm{dd}, 1 \mathrm{H}, \mathrm{J}=8.0$ and $16.0 \mathrm{~Hz}), 2.18-1.25(\mathrm{~m}$, $12 \mathrm{H}) .{ }^{13} \mathrm{C} \mathrm{NMR}, \delta\left(75 \mathrm{MHz}, \mathrm{CDCl}_{3}\right)$ : $133.3,129.4$, 128.0, 124.4, 124.1, 123.5, 34.9, 34.4, 31.9, 31.6, $30.2,28.9,27.1,22.7$.

\subsubsection{1-phenylseleno-2-(azido)heptane}

IR (neat) $\left(v_{\max }, \mathrm{cm}^{-1}\right): 2094(\mathrm{~N}=\mathrm{N}-\mathrm{N}-), 1573,1470$, 1265 (=C-H aromatic), 986, 864, 838 and 756 $\mathrm{cm}^{-1} .{ }^{1} \mathrm{HNMR}, \delta\left(300 \mathrm{MHz}, \mathrm{CDCl}_{3}\right): 7.61-7.58(\mathrm{~m}$, $2 \mathrm{H}), 7.39-7.34(\mathrm{~m}, 3 \mathrm{H}), 3.37(\mathrm{dd}, 1 \mathrm{H}, \mathrm{J}=7.9$ and 12.6 $\mathrm{Hz}), 3.25(\mathrm{dd}, 1 \mathrm{H}, \mathrm{J}=6.5$ and $12.6 \mathrm{~Hz}), 2.04-0.83(\mathrm{~m}$, 11H). ${ }^{13} \mathrm{C} \mathrm{NMR,} \delta\left(75 \mathrm{MHz}, \mathrm{CDCl}_{3}\right): 143.4,137.3$, $132.9,129.6,128.9,127.3,62.1,58.6,34.8,32.4$, 24.3, 23.4, 21.6 .

\section{Results and discussions}

\subsection{Cyclic voltammetry}

Cyclic voltammogram of a platinum electrode to $(\mathrm{PhSe})_{2}$ in anhydrous dimethyl formamide containing M TBAP at a sweep rate of $100 \mathrm{mv} \mathrm{s}^{-1}$ in the absence and presence of cyclohexene and sodium azide (excess amount) is shown in Figure 1. This figure shows an oxidative peak (1a) at 1.75 
$\mathrm{V}$ (vs. $\mathrm{Ag} / \mathrm{AgCl}$ ), which is consisted with oxidation of $(\mathrm{PhSe})_{2}$ to the phenylselenenyl cation. Cyclic voltammogram of $(\mathrm{PhSe})_{2}$ in the presence of $\mathrm{C}_{6} \mathrm{H}_{10}$ and $\mathrm{NaN}_{3}$ shows two oxidative peaks (2a, 3a) at $1 \mathrm{~V}$ and $1.96 \mathrm{~V}$. The cyclic voltammetry experiments of the mixture of $(\mathrm{PhSe})_{2}, \mathrm{C}_{6} \mathrm{H}_{10}$, and $\mathrm{NaN}_{3}$ were performed in different potential sweep rates of $40-700 \mathrm{mv} \mathrm{s}^{-1}$ (Fig. 2). The results of cyclic voltammogram of figure 2 show an increase in the height of anodic peak and oxidation potential. The linear relation of the peak current of $1 \mathrm{~V}$ vs. square root of sweep rate obtained with data of figure 2 confirms the departure from diffusion control. The multi-cyclic voltammograms of $4 \mathrm{mM}(\mathrm{PhSe})_{2}$ and excess amount of $\mathrm{C}_{6} \mathrm{H}_{10}$ and $\mathrm{NaN}_{3}$ show a decrease in second scan of anodic peak. After second scan, anodic peak becomes constant (Fig. 3). We seached several conditions for finding optimum results. Firstly, different solvents are used in the experiments. Acetonitryl was not suitable solvent because of reaction with phenylselenyl cation. The second oxidation peak shows it in figure 4 . Kunai et al. postulated a reaction between $\mathrm{PhSe}^{+}, \mathrm{CH}_{3} \mathrm{CN}$ in the presence cyclohexene [9]. So we abandoned this solvent. Dimethyl formamide was very suitable solvent for this reaction. Cyclic voltammetry confirmed this well. In addition to solving well all reactants, it did not show any oxidation peaks in the potential limit.

By supporting the electrolyte which was optimized for this reaction, it is suggested by a method for increasing yield with bromide ion of electrolyte Torii et al. This anion obtained the reactive mediator as $\mathrm{PhSeBr}$ with $\mathrm{PhSe}^{+}$[17]. Tetrabutylammonium bromide (TBAB) as supporting electrolyte could not prepare the expectant results. In figure 5, cyclovoltammograms confirmed it, and difference of oxidation peak of TBAB and tetrabutylammonium perchlorate (TBAP) is absolutely. Table 1 shows the synthesized products of different alkenes and their yields.

\subsection{Constant voltage electrolysis}

The controlled-potential coulometry was performed in organic solution which is contained $0.3 \mathrm{mmol}$ of $(\mathrm{PhSe})_{2}$ and excess amount of $\mathrm{C}_{6} \mathrm{H}_{10}$ and $\mathrm{NaN}_{3}$ at constant anodic potential of $1.96 \mathrm{~V}$ (vs. $\mathrm{Ag} / \mathrm{AgCl}$ ) with an H-type divided cell. Poor results received with undivided cell. The electrolysis was performed between 3-5 $\mathrm{h}$, depending on the passed charge for the reaction. The monitoring of electrolysis was performed by TLC and cyclic voltammetry.

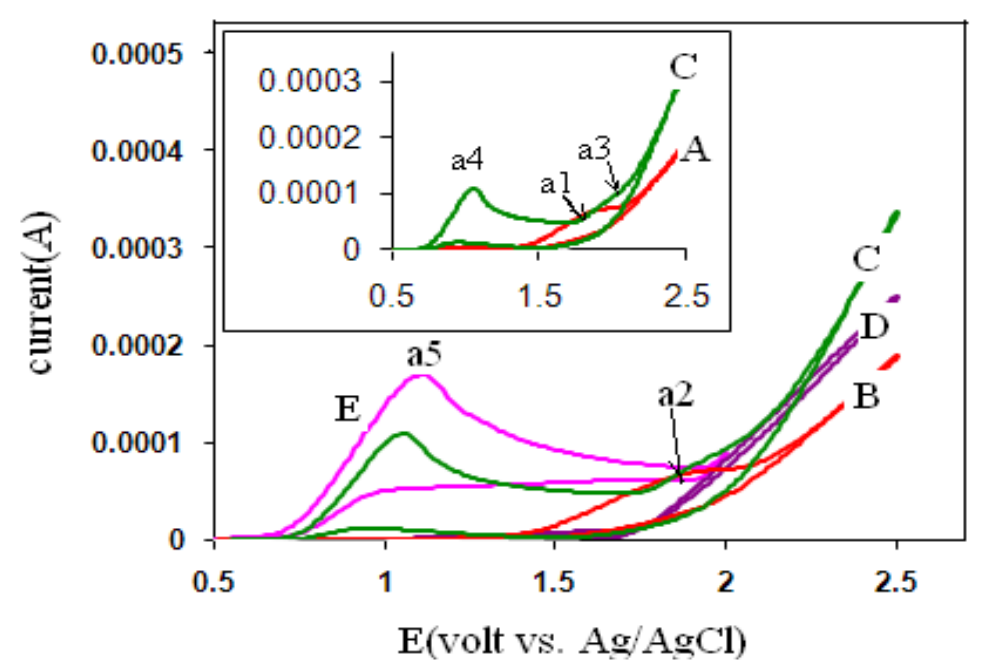

Fig. 1. Cyclic voltammogram of $4 \mathrm{mM}\left(\mathrm{phSe}_{2}(\mathrm{~A}), 4 \mathrm{mM}(\mathrm{phSe})_{2}\right.$ in the presence of $\mathrm{C}_{6} \mathrm{H}_{10}(\mathrm{~B}), 4 \mathrm{mM}(\mathrm{phSe})_{2}$ in the presence of $\mathrm{C}_{6} \mathrm{H}_{10}$ and $\mathrm{NaN}_{3}(\mathrm{C}), \mathrm{C}_{6} \mathrm{H}_{10}(\mathrm{D}), \mathrm{NaN}_{3}(\mathrm{E})$ with $0.2 \mathrm{M}$ TBAP at a platinum electrode. Potential sweep rate was $100 \mathrm{mVs}^{-1}$. 


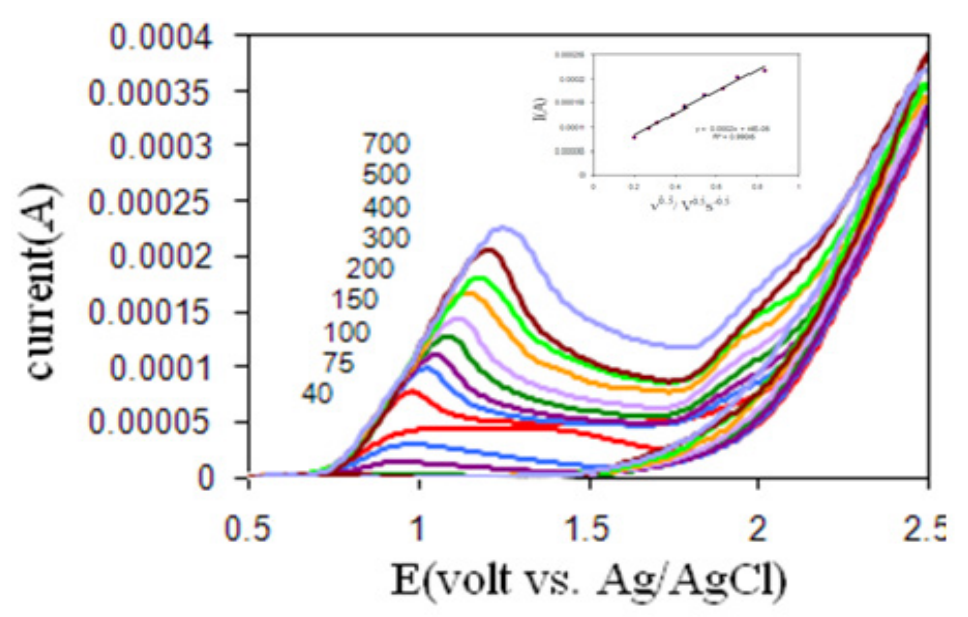

Fig. 2. Cyclic voltammograms of $4 \mathrm{mM}(\mathrm{phSe})_{2}$ and $0.2 \mathrm{M} \mathrm{TBAP}$ in the presence of excess amounts of $\mathrm{C}_{6} \mathrm{H}_{10}$ and $\mathrm{NaN}_{3}$ at a platinum electrode and at different potential sweep rates $\left(40-700 \mathrm{mVs}^{-1}\right)$.

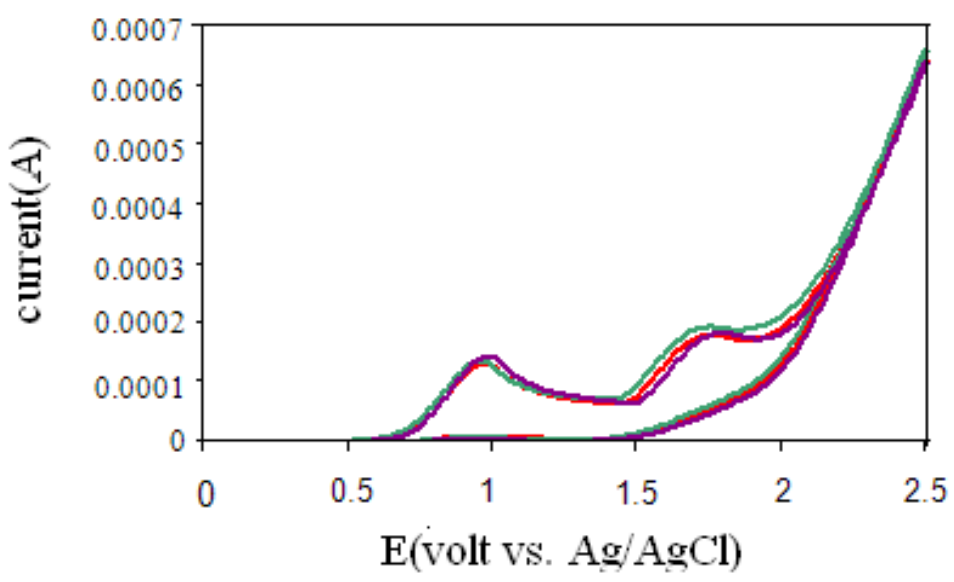

Fig. 3. Multi-cyclic voltammograms of $4 \mathrm{mM}(\mathrm{phSe})_{2}$ and $0.2 \mathrm{M} \mathrm{TBAP}$ in the presence of excess amounts of $\mathrm{C}_{6} \mathrm{H}_{10}$ and $\mathrm{NaN}_{3}$ at a platinum electrode. Potential sweep rate was $100 \mathrm{mV} \cdot \mathrm{s}^{-1}$.

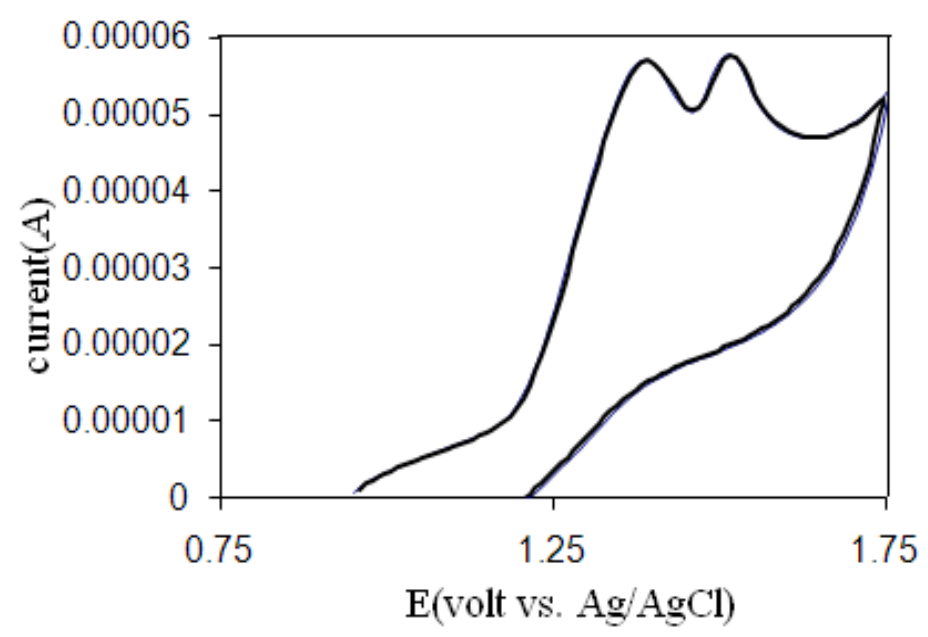

Fig. 4. Cyclic voltammogram of $4 \mathrm{mM}(\mathrm{phSe})_{2}$ and $0.2 \mathrm{M}$ TBAP in $\mathrm{CH}_{3} \mathrm{CN}$ at a platinum electrode. Potential sweep rate was $100 \mathrm{mVs}^{-1}$. 


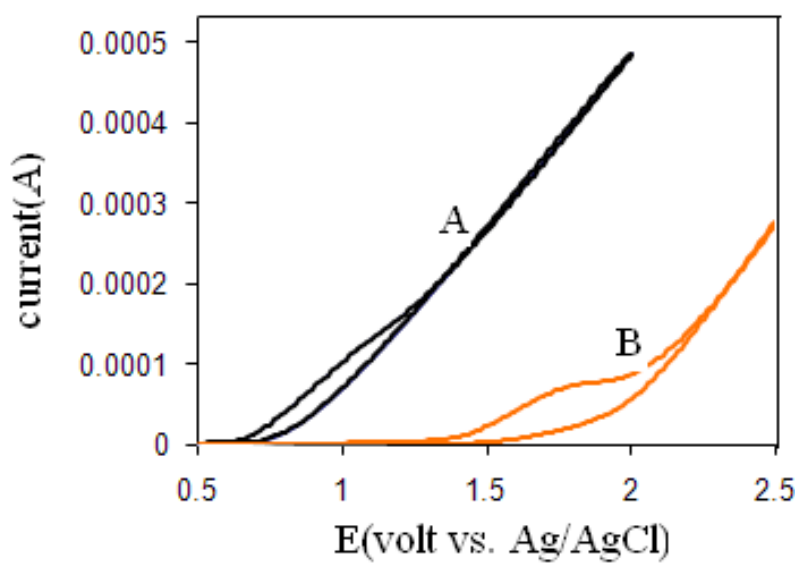

Fig. 5. Cyclic voltammograms of $4 \mathrm{mM}(\mathrm{phSe})_{2}$ in the presence of excess amounts of $\mathrm{C}_{6} \mathrm{H}_{10}$ and $\mathrm{NaN}_{3}$ at a platinum electrode. Supporting electrolytes were tetrabutylammonium bromide (A), tetrabutylammonium Perchlorate (B). Potential sweep rate was $100 \mathrm{mV} \cdot \mathrm{s}^{-1}$.

Table 1. The synthesized products of different alkenes and their yields.

Entry

Moreover, it was shown a decrease in the anodic peak current of the product during various times of the electrolysis progressing (Fig. 6).

$\mathrm{N}$-value of about 2 electrons calculated for controlled-potential coulometry at the potential of $1.96 \mathrm{~V}$. The mechanism of electrochemical azido- selenenylation of olefins proposed EC reaction which the olefins react with the phenylselenenyl cation of the oxidative $(\mathrm{PhSe})_{2}$ in a nucleophilic addition fashion. This reaction generated the intermediate of selenyranium cation which was reacted with Sodium azide for synthesis of the 


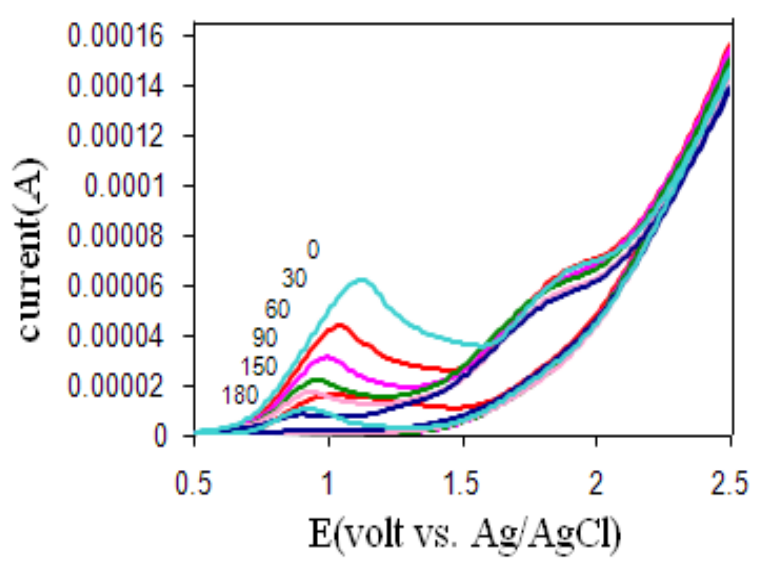

Fig. 6. Cyclic voltammograms of $4 \mathrm{mM}(\mathrm{phSe})_{2}$ and $0.2 \mathrm{M}$ TBAP in the presence of excess amounts of $\mathrm{C}_{6} \mathrm{H}_{10}$ and $\mathrm{NaN}_{3}$ at a platinum electrode during controlled potential coulometry versus $\mathrm{Ag} / \mathrm{AgCl}$. Potential sweep rate was $100 \mathrm{mV} . \mathrm{s}^{-1}$.

product (scheme 1). The results of IR spectroscopy of the final product show removal of $\mathrm{C}=\mathrm{C}$ band for vinylil group in $1662 \mathrm{~cm}^{-1}$. A relatively strong adsorption band disappeared for $\mathrm{N}-\mathrm{N}=\mathrm{N}$ group of $\mathrm{NaN}_{3}$ in $2095 \mathrm{~cm}^{-1}$.

\section{Conclusions}

In this paper, olefins and Sodium azide as nucleophile reacted with phenylselenenyl cation derived from electrochemical oxidation of $(\mathrm{PhSe})_{2}$. This progress was leading to the formation of azido-phenylselenenyl functionalized product with Markovnikov reaction. The final product was received a relatively good yield (60\%). Like prior papers [4], regeneration of diphenyl diselenide was caused low yield of the product. The study of cyclic voltammograms and coulometric data was confirmed EC mechanism for electrochemical azido-selenenylation of olefins. The results and conditions of this project are better of the organic azido-selenenylation reactions [13, 20].
In comparison of organic reactions, the present electrochemical method considers being ineffective because of easier conditions (room temperature and atmosphere pressure), using lower amounts of reactants, not used catalysts, relatively short reaction times, high purity, and selectivity.

\section{References}

[1] L. Prashanth, K. K. Kattapagari, R. T. Chitturi, V. R. Reddy Baddam, L. K. Prasa, A review on role of essential trace elements in health and disease, J. Dr. NTR Un. Health Sci., 4 (2015) 75-85.

[2]V. Gandin, P. Khalkar,J. Braude, A. P. Fernandes, Organic selenium compounds as potential chemotherapeutic agents for improved cancer treatment, Free Radical Biol. Med.,127 (2018) 8097.

[3] R. L. Quispe, M. L. Jaramillo, L. S. Galant, D. Engel, A. L. Dafre, J. B. Teixeira da Rocha, R. Radi, M. Farina, A. F. de Bem, Diphenyl diselenide protects neuronal cells against oxidative stress and

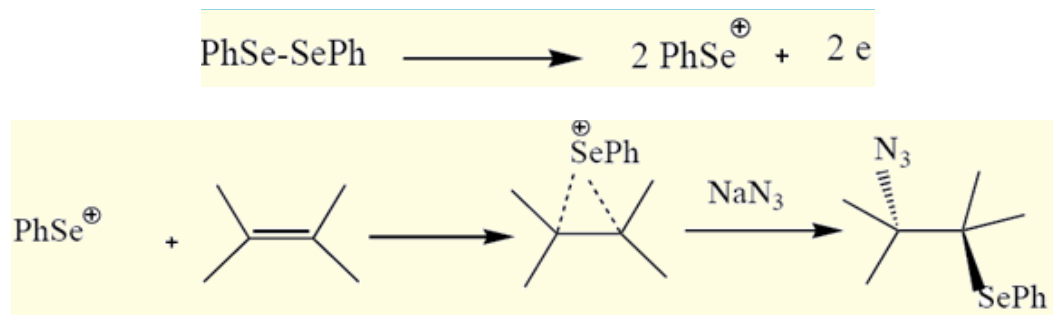

Scheme 1. Mechanism of Reaction. 
mitochondrial dysfunction: Involvement of the glutathione-dependent antioxidant system, Redox Biol., 20 (2019) 118-129.

[4] A. R. Patra, S. Singha Roy, A. Basu, A. Bhuniya, A. Bhattacharjee, S. Hajra, U. Hossain Sk, R.Baral, S. Bhattacharya, Design and synthesis of coumarin-based organoselenium as a new hit for myeloprotection and synergistic therapeutic efficacy in adjuvant therapy Scientific Reportsvolume 8, Article number: 2194 (2018)

[5] C. Narajji, M. D. Karvekar, A. K. Das, Biological importance of organoselenium compounds, Indian J. Pharm. Sci., 69 (2007) 344-351.

[6]E. J.Lenardão, C. Santi, L. Sancineto, Organoselenium compounds as reagents and catalysts to develop new green protocols, New Frontiers in Organoselenium Compounds, 2018, pp. 1-97, 2018.

[7] H. D. S. Souza, R. P. F. de Sousa, B. F. Lira, R. F. Vilela, N. H. P. B. Borges, J. P. de Siqueira-Junior, E. O. Lima, J. U. G. Jardim, G. A. T. da Silva, J. M. Barbosa-Filho, P. F. de Athayde-Filho, Synthesis, in silico study and antimicrobial evaluation of new selenoglycolicamides, Braz. Chem. Soc., 30 (2019) 188-197.

[8]C. Santi, R.G. Jacob, B. Monti, L. Bagnoli, L. Sancineto , E.J. Lenardão , Review: Water and aqueous mixtures as convenient alternative media for organoselenium chemistry, Molecules, 21 (2016) 1482.

[9]A. Tepecik, Z.Altin, S. Erturan, The Diorganoselenium and Selenides Compounds Electrochemistry J. Autom. Methods Manage. Chem. 1 (2008) 1-6.

[10] S. Möhle, M. Zirbes, E. Rodrigo, T. Gieshoff, A. Wiebe, S. R. Waldvogel, Modern Electrochemical Aspects for the Synthesis of Value-Added Organic Products, Angew.Chem. Int. Ed., 57 (2018) 60186041.

[11] A. Kunai, J. Harada, J. Izumi, H. Tachihara, K. Sasaki, Anodic oxidation of diphenyldiselenide in acetonitrile, Electrochim. Acta, 28 (1983) 13611366.

[12] O. Niyomura, M. Cox, T. Wirth, Electrochemical
Generation and Catalytic Use of Selenium Electrophiles, Synlett, 2 (2006) 251-254.

[13] M. Tingoli, M. Tiecco, D. Chianelli, . Balducci, A. Temperini, Novel azido-phenylselenenylation of double bonds: Evidence for a free-radical process, J. Org. Chem., 56 (1991) 6809-6813.

[14] D. S. Smith, J. Winnick, Y. Ding, L. A. Bottomley, Electrosynthesis of Alpha-keto Acetals, Electrochim. Acta, 43 (1998) 335-339.

[15] M. Tingoli, M. Tiecco, L. Testaferri, R. Andrenacci, R. Balducci, Intramolecular nucleophilic deselenenylation reactions promoted by benzeneselenenyl triflate. stereospecific synthesis of vicinal amino alcohol precursors J. Org. Chem. 58 (1993) 6097.

[16] B. I. Kharisov, Direct synthesis of metal complexes, Elsevier, Switzerland, 2018.

[17] Fundamentals and applications of organic electrochemistry: synthesis, materials, devices, T. Fuchigami, M. Atobe, S. Inagi, Wiley, United Kingdom, Edition 2015.

[18] E. Steckhan, Topics in Current Chemistry, Vol. 185, Springer-Verlag, Berlin, 1997, Chapter 3.

[19] C. Gütz, B. Klöckner, S. R. Waldvogel, Electrochemical screening for electroorganic synthesis, Org. Process Res. Dev., 20 (2016) 2632.

[20] S. Torri, K. Uneyama, K. Handa, Research articleAbstract only A facile access to $\alpha$-phenylselenenyl carbonyl compounds by electrochemical oxidation, Tetrahedron Lett., 21 (1980) 1863-1866.

[21] R. Mundil, A. Sokolohorskyj, J. Hošek, J. Cvačka, I. Císařová, J. Kvíčala, J. Merna, Nickel and palladium complexes with fluorinated alkyl substituted $\alpha$-diimine ligands for living controlled olefin polymerization, Polym. Chem., 9 (2018) 1234-1248.

[22] L. M. Bouchet, J. E. Argüello, Photoinduced oneelectron oxidation of aromatic selenides: effect of the structure on the reversible dimerization reaction, J. Org. Chem., 83 (2018), 5674-5680 